\title{
全運動軸の描記法による求め方
}

\author{
河野正司福島俊士

\section{Determination of the Kinematic Axis with the Tracing Method}

\author{
Shoji Kohno and Shunji Fukushima
}

\section{I.はじめに}

回枟しながら移動する性梊をもつ顆頭の運動は，測定 点の位固により運動径路が著しく異なるため, 下影運動 の解析さらに再現にあたつて大きな障害となつていた。

しかし「全通動帖 Kinematic Axis」が発見される1, 2,3) に至って，下䫑の矢状面内通動の全てを，顆頭上に 存在する全通動軸を中心とした回転と，極く㻖い帯状な 顆路の上の移動の 2 要素に分離することが可能となっ た. この全遇動軸は下颖のあらゆる矢状面内運動に対し て，一定な顆路の上を前後的に移動するものとして対応 しているから，顆頭の全ての通動を全運動枓によって 1 つの点の運動として表わせることになる．換言すれば， 運動論的に根拠のある顆頭代表点として，全運動軸を位 瞋づけることができることになる。

このことの故に, 全通杪軸は 2 次元の矢状面内の下䂓

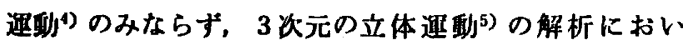
て, 顆頭部の测定点として大きな意義を持って使用され ている.

また咬合器上に下䫟運動を再現する際の顆路の湘定点 として，全運動軸は蝶番軸とは異なる優れた性質を持つ ている.すなわち，蝶番軸を測定点とした埸合には，咬 合高径の変化や，迅政のガイドが異なることによつて， 顆路が大きく翼なって記録されるといら現象6,7) が見ら

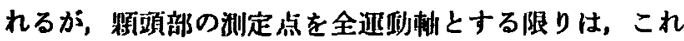
らの条件に左右されることなく常に一定の顆路が記録さ れる.

以上述へたごとく，全巡秒渭によって下類の全迅副の

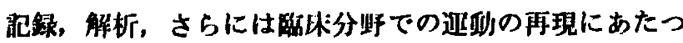
て，新たな基滥を得ることができたと考えられる。

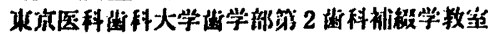

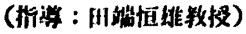

Dept. of Prosthetic Dentistry, School of Dentistry, Tokyo Medical and Dental University (Director: Prof. Tsuneo Tabata)

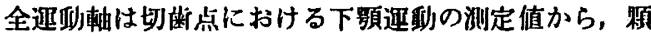
頭運的路を算出する方法によつて確認されたものであ る.しかし顔弓を利用した描記法によつて全運動軸を求 めることも可能であり, 顆頭運動を測定する際の测定点 の決定にあたつて，大きな利用似値を持つものである゙).

本論文では，描記法による全運動軸の決定法の原理， ならびにその術式について記すことにしたい.

\section{II. 全軍動軸の求め方の原理}

全迅秒䖩は既に報告》さされているごとく，矢状面内の 全ての逝儌に対応して，顆頭部で記録される上下的な幅 の最小な荤盼範囲を示す点である．顔弓を使用した描記 法によってこの点を求める方法は，下顎の矢状面内限界

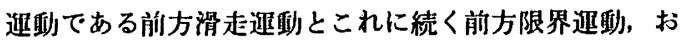
よび後方限界運㓰によつて構成される運動範围を描記さ せ，上下的に最も怗い運動筙目を描く点を全进動軸とし て，試行錯誤的に求めるものである.

全迅動軸は次のごとき性質を持つものであるから”， 实際の描記にあたつては，この性啠を利用することによ つて能率良く位㯰を決定することができる.

\section{1. 運動籍围を構成する限界路の性質}

全運動軸を中心として顆頭は回転し，前後的に移秒し ているため，全迅吵檕を中心としてその周畍の点では，

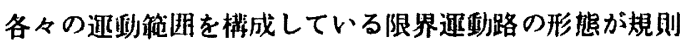

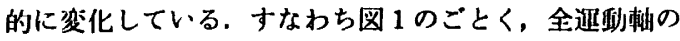
前方点 (A) では，前方滑走路および前方限界路が迅政節 阳の上限を，後方限界路がその下限を構成している。こ

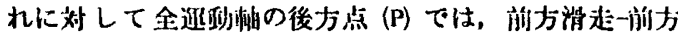
限界路が迎弫箱朋の下限を，後方限界路が、上限を楼成し

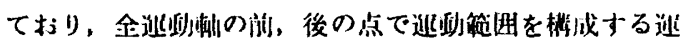
㔜路が近の激俰となつている。

\section{2. 運動籍囲の上下幅の変化}

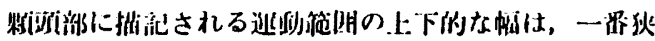

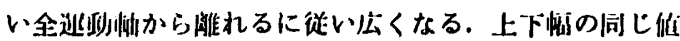




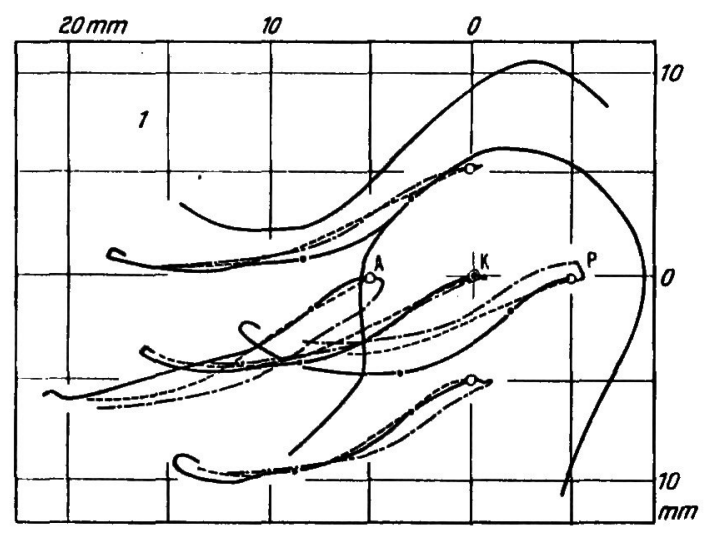

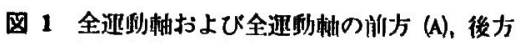

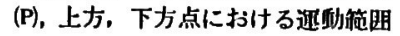

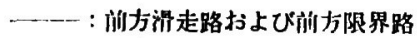

- - : 後方限界路

- - - : 開口路

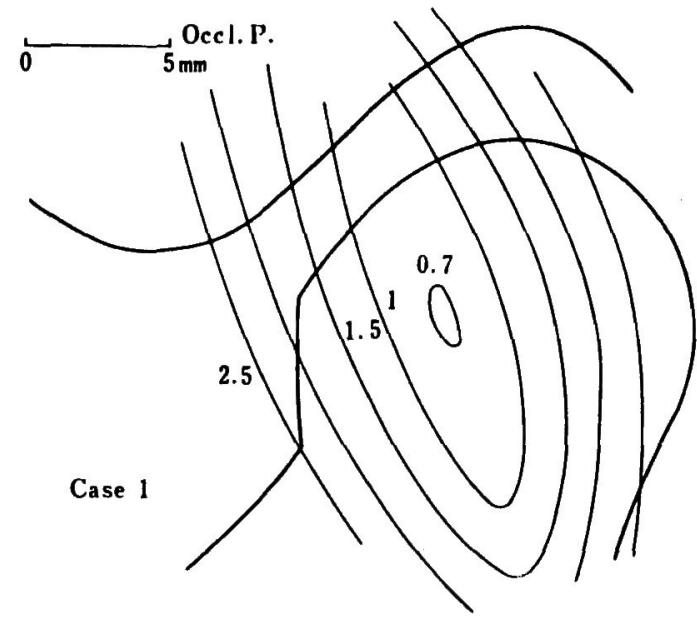

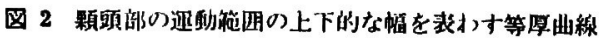

をもつ点を求め，曲線で結ふと，図 2 のごとく，咬合平 面に対して約 $10^{\circ}$ 前方に傾斜して上下方向に長軸を持 つほほ等間隔にならぶ楠円状の曲線となる。

この曲線から，測定点が咬合平面に対して顆頭部を上 下方向に移畊した時に比べて, 前後方向に位直が変化す

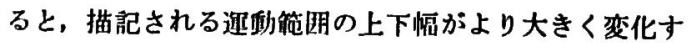
えことを知ることができる。

\section{3. 全運動軸と平均的顆頭点との関係}

颗嘼上の全巡的梢は，いわゆる蝶采妕よりもむしろ 㖄耳平而上の年珠i们方 $13 \mathrm{~mm}$ にある平均的顆頭点に近 接して存在している傾们が認められるり。この現魚は,

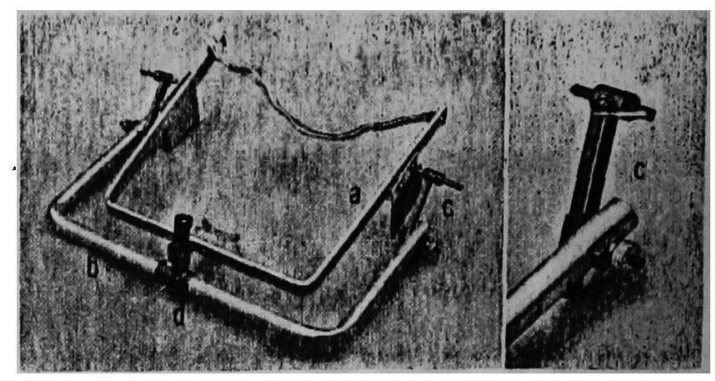

因 3 描記装睡
a : 上顆顔弓と描記板
b：下暍顔亏

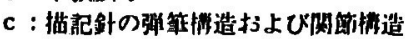
d：下影クラッ千固定装暀

全飠動軸を描記法によつて求めるにあたり，描記針をま ず平均的顆頭点に定位してから，試行錯唄的に求めてゆ くことが能率的であることを示唆している.

\section{III. 描記法による術式}

\section{1、描記装軍}

上䫑の顆頭該当部に固定された描記板上に，一下額齿列 に固定した顆路描記針によつて運䡃径路が描ける装圈を 使用する. 描記装置のうち，下影に固定した描部針が， 顆頭周辺の任意の位固を容易にとることが江来る满造に なつていることが, さらに望ましい.

いわゆる蝶番軸を求めるために製作された Hingelocator や, Stuart, Granger 等の顆路捛記装居も使用 することが出来るが，著者らは図 3 に示す描記装眉を製 作し, 使用している.

この描記装圈では，顆路を出来る限り細い線で描記す るために，描記板として平消なガラス板を用い，これに Gothic-arch Tracing 用のインク*を慧布して使用し ている.一方, 描記部は㨁径 $3 \mathrm{~mm}$ の真䤣棒を十分鋔 利に研整したものを描記針として，群筷棈造となつてい る. また下䪽顔弓と描記部の間には関節があり,この部 分を調節することによつて，描記針が顆頭周辺の位置を 任意にとることが出来るように作られている.

\section{2. 全運勤軸の決定法}

1）下影顔弓の装着

顆頭部に描記針の付いた顔弓をクラッチを介して下顥 临列に固定する.

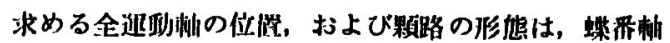
における场合とは舆なり，咬合高径の峦化や迅的のガイ

- Dentspley(i)-Tracing Fluid : Dentsply International INC. 500 West College Ave., York, Pa. U.S.A. 


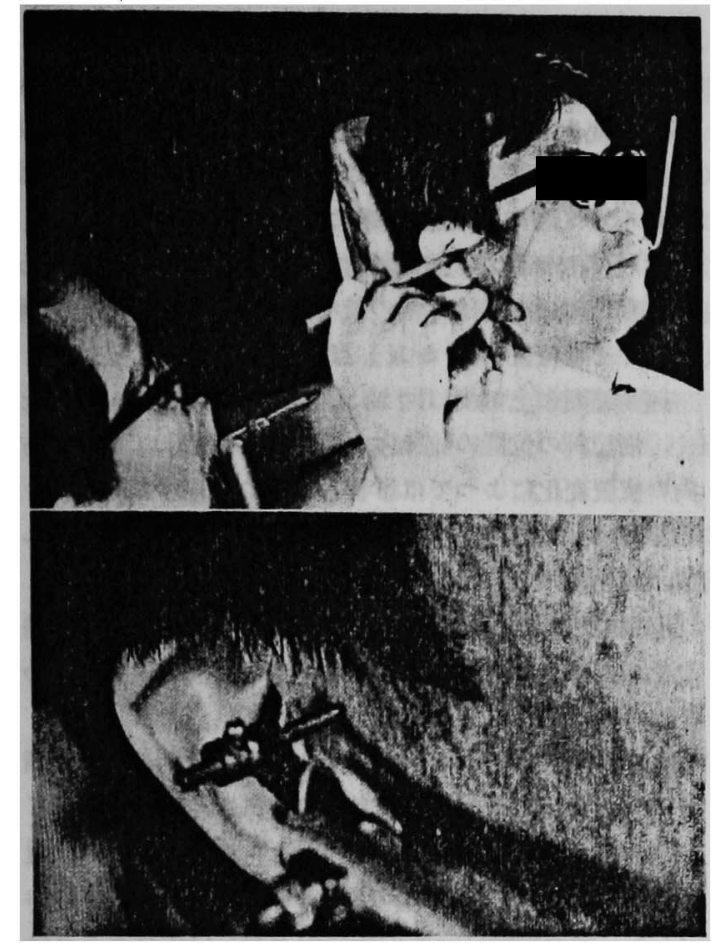

图 4 平均的颊頭点の標記および描巽針の定位

ドに影響されないという性質を持つている.この利点の 故に，顔弓を周定するクラッチは，咬合面を覆う形式の しのであつても，徣わぬものであつても良く，製作の 简便なレジン製のクラッチも使用することも可能であ る.

\section{2）描記針の定位}

平均的顆頭点として根耳平面上の耳珠削方 $13 \mathrm{~mm} の$ 点を皮席上に記録し，この点に描記針の先を一致させて 風定する (図 4 ).

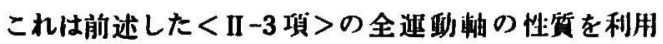
ナるためである.

\section{3) 描記板の固定}

上䪿部の描記板は，迅動の記録㭙に動摇の無いことが 絶対の要件である. 固定方法は, 上顥列列にクラッチを 介して頌弓を固定，もしくは図 5 のごとくに頭部に直接 颜弓を固定することにより，描記板を顆頭部に定位す る. 全迺動軜と共に描記された顆路を咬合器上に再現し ない物合，ナなわち全進政軸を求めるのみであれば，後 者のような简易な描記板四定泣でも秒摇することなくけ 少の上うでむむ.

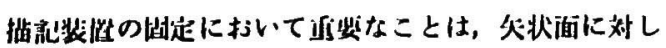

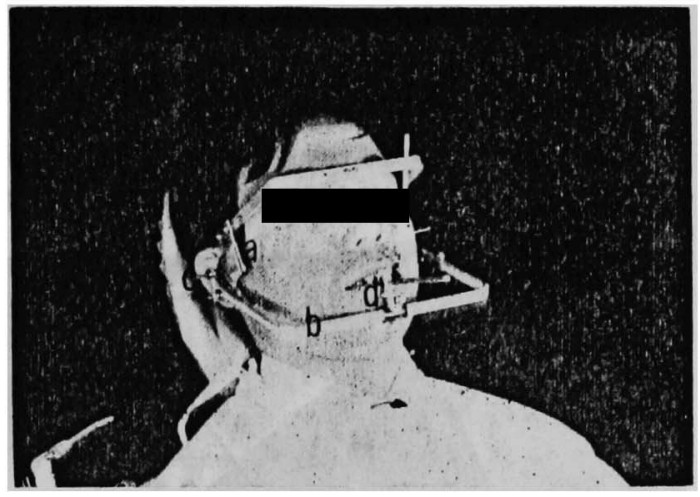

图 5 描跑装圈の装着状柋
a : 满施极
b : 下影颜弓

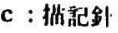

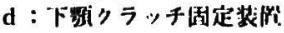

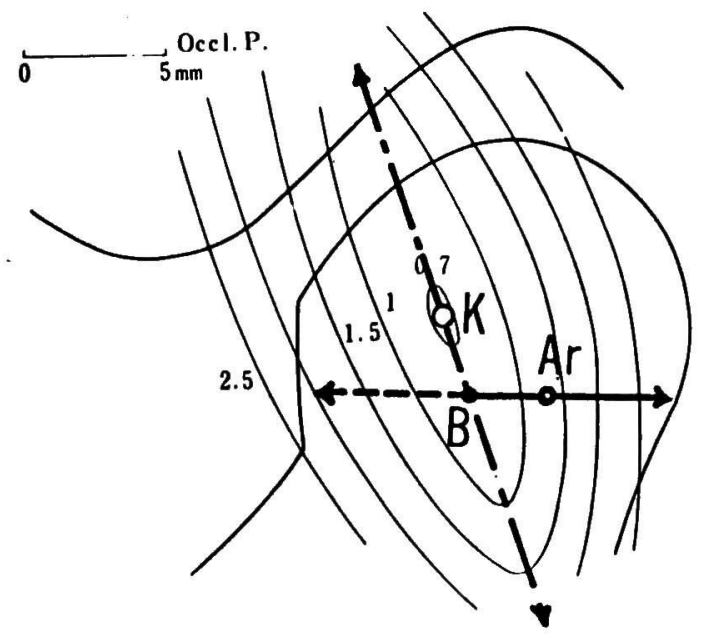

図 6 描記釗の移動方法

Ar : 将均的顆环怘

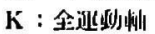

B点を境に顆頭部の前方点と後方点では荤動

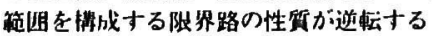

て描記板が平行に，さらに描記針が描記板に対して重直 に定位されていることである.これが守られぬ場合に は，矢状面内の诹動籁四が正確に描記されず，上下的な 愊にも影刻を及ぼしてくる。

4) 描記針の移的方洪:

全进動軸を試行錯話的に探しはJす際，描記針の位愠を

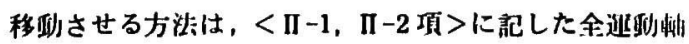
ひ恘行を利川小を。

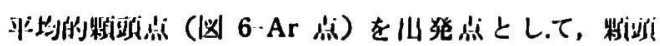


部の前一後方向人描記針を移動しながら数点において， 前方滑势路とこれに続く的方限界路，抢よび後方限界路 を描記させて，各々の迅動提囲を求める.

描かれる迅動径路は全迅動斬の後方の点では, 前方滑 走路および前方限界路が後方限界路に対して下方に位置

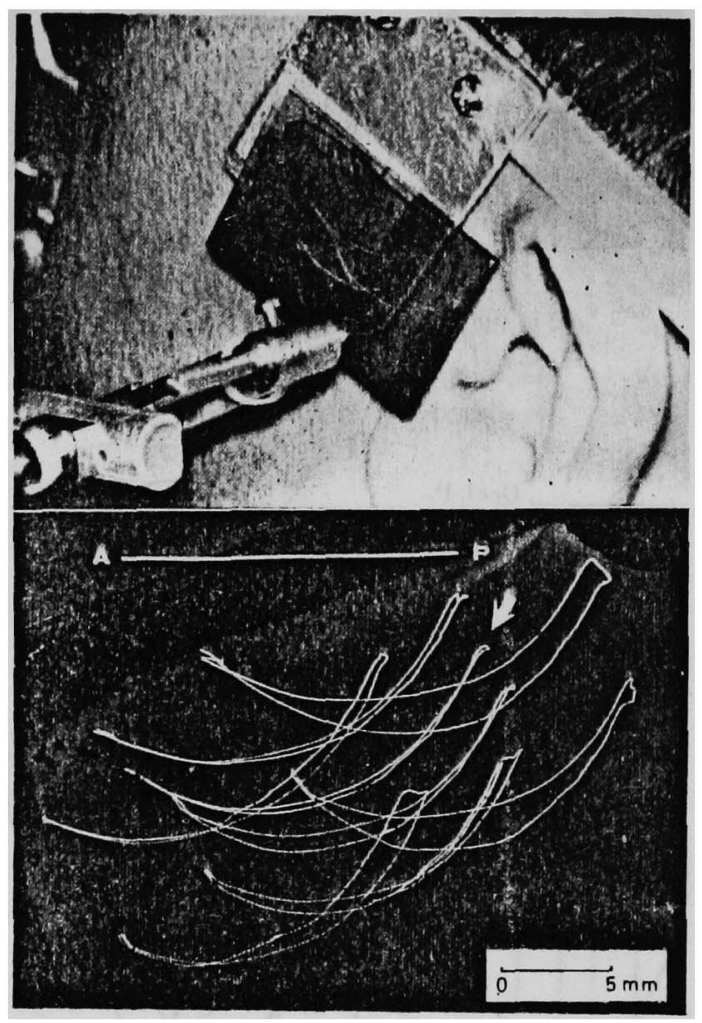

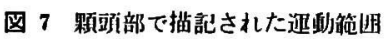
上下的に最小な幅の迺動笵囲（矢印）を描く点と して全进動䡛が冰まる

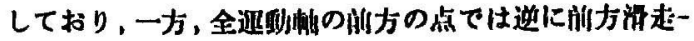

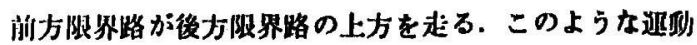
径路の変化を考战しつつ，描記針を剖後方向に移䡃させ

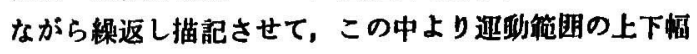
の最小点 (図 6-B点) を求める.

次いで，B点より描記針を上下方向人移動して，さら

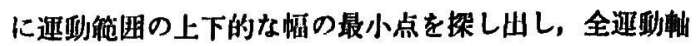
としてその位置 (図 6-K) 点を求める.

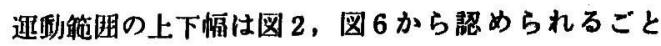
く，描記針の位㯰の前後方向の变化に比較して，上下方 向の位置変化によつては影響されることが少ないため, 描記針の上下方向一の移動は前後方向よりも大きくし て，運動範阘を描記させる必要がある.

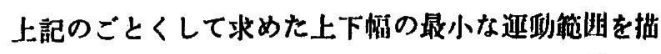
記する点が全運動軸であり，描記された極く狭い䘗状の 径路が矢状顆路である（図7, 図 8).

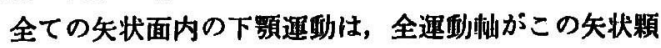
路の上を回転しながら移拜することによつて行なわ机て おり，図8のごとく，上頻咬合面をレジンシーネで賣 い，咬合高径および運動の指導要素が变化した状㑫にお いても，全荤䟞岫は一定の顆路の上からはずれることは ない.

\section{IV.おわりに}

全迅㔚軸はその性質上，軸の位置の決定と同時に，矢 状顆路をも描記出来るという, 蝶番㠼とは琵なる特脣を 持っている.

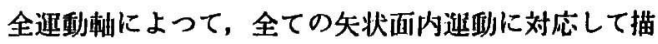
記される矢状顆路は, 先の報告1)のごとく，顆頭の形始 や関節円板の被圧縮性に影響されて, 図 7, 図8のごと く上下的に 0.5 1 mm の幅を持っている. 殊に描記法

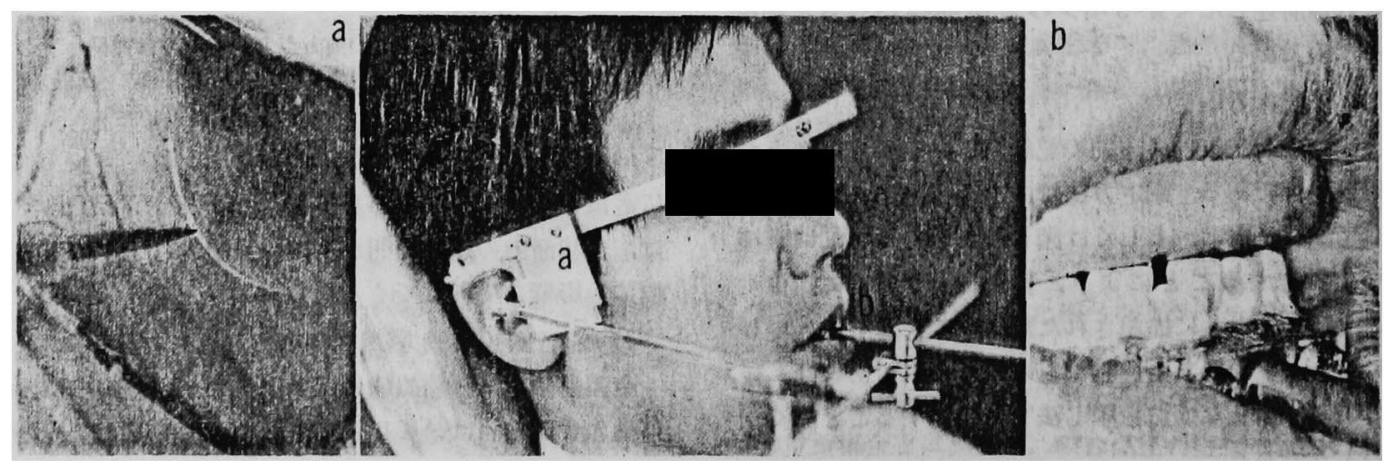

图 8 全迅秒俥によって描記された矢状顆路

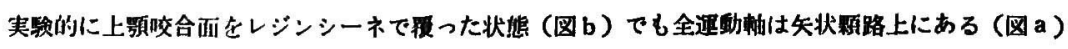




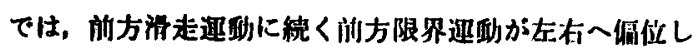

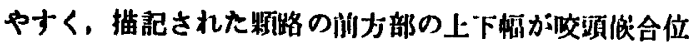
側に较へ広くなりやすい。

しかし，全迅㽖䡛の位置は，矢状面限界運動の径路の 変化に影算されることが，蝶番軸に校べきわ少な く，下䫑運動の測定，再現の基点としての安定性に非常

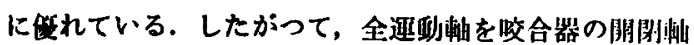
に移し，顆路を再現することによって，速㲜の再現能力

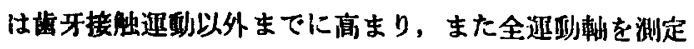
点として, 下頻の立体運動を测定, 解析することが可能 になるといえる.

このような多くの特長を持つた全䢖秒刺は, 本䜽文に 記した描記法によって简単に求めることができ, 顆顽逊

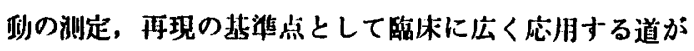
閒かれたと考える.

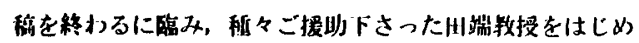

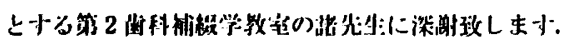

\section{文献}

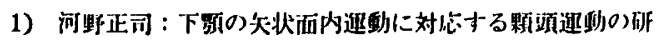
究，第 2 報、ーマルチフラッシュ装圆による矢状面迅動軸 の解析，補銀鼓， $12: 350 ， 1968$.

2) Kohno, S., and Ishiwara, T.: Analysis of movement of mandibular condyle in sagittal plane, Bull. Tokyo Med. Dent. Univ., $18: 233,1971$.

3) Kohno, S. : Analyse der Kondylenbewegung in der Sagittalebene, Dtsch. zahnärztl. Z., 27 : 739, 1972.

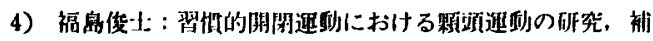
緅誌, $15: 267,1971$.

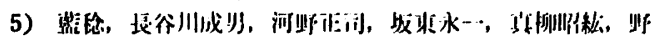

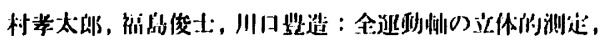
第 13 国山本幽科㗨学会総会分科会, 補緅学会, 1973.

6) Shanahan, T.E.J. et al. : Mandibular and articular movements, Part VII. Concepts of lateral movements and condyle paths. J. Prosthet. Dent., 14 : 279, 1964.

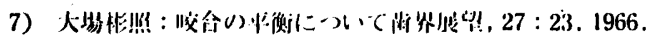

